\title{
John Haltiwanger: recipient of the 2020 Global Award for Entrepreneurship Research
}

\author{
Alex Coad - Martin Andersson • Magnus Henrekson • Sarah Jack • \\ Mikael Stenkula $\cdot$ Karin Thorburn $\cdot$ Karl Wennberg $\cdot$ Ivo Zander
}

Accepted: 1 June 2021 / Published online: 20 August 2021

(C) The Author(s) 2021

\begin{abstract}
The 2020 Global Award for Entrepreneurship Research has been awarded to Professor John Haltiwanger. John Haltiwanger has made significant contributions to the field of entrepreneurship by improving our understanding of job creation and destruction, productivity growth, and the role of small- and medium-sized firms (SMEs) in economic development. He has played a major role in the careful development of large, longitudinal firm-level datasets, and introduced a novel and widely adopted measure of firm growth that addresses previous statistical biases. His work has influenced public policy and national statistical offices around the world.
\end{abstract}

Plain English Summary The winner of the 2020 Global Award for Entrepreneurship Research, John

\section{A. Coad}

Waseda Business School, Waseda University, Tokyo, Japan

M. Andersson

Entreprenörskapsforum, Grevgatan 34,

SE-114 53 Stockholm, Sweden

M. Henrekson · M. Stenkula $(\bowtie)$

Research Institute of Industrial Economics, P.O. Box 55665, SE-102 15 Stockholm, Sweden e-mail: Mikael.Stenkula@ifn.se

S. Jack

Stockholm School of Economics, P.O. Box 6501,

SE-113 83 Stockholm, Sweden
Haltiwanger, has pioneered research showing that it is mainly firm age, not size, that matters for job creation. Through analyzing the relationship between employment, growth, and firms, he has advanced our understanding of how the economy works. He has done this by building new datasets and introducing a new measure of firm growth, solving problems encountered with earlier techniques. His work has also broadened the policy debate on entrepreneurship and inspired people all around the world. From a policy perspective, John Haltiwanger has shown that it is difficult to justify targeted industrial and commercial policies, and if job creation is to be supported, politicians need to target young firms rather than small firms. These important findings from John Haltiwanger's pioneering work have been published in world-class leading academic and scientific journals.

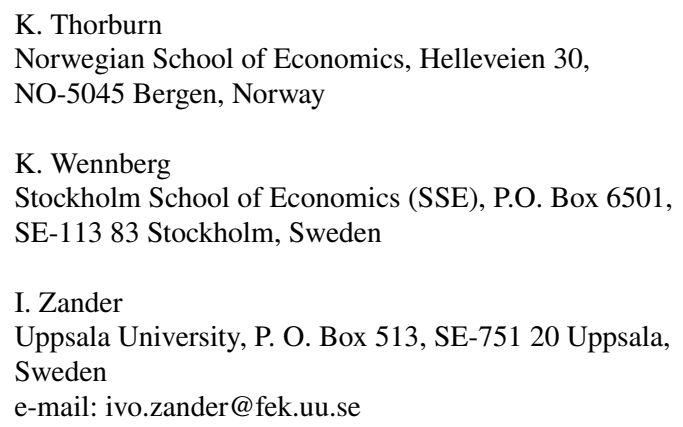


Keywords Global Award for Entrepreneurship Research · Entrepreneurship · Firm dynamics

JEL Classifications $\quad$ L26 $\cdot$ M13 $\cdot$ D22 $\cdot$ L22

\section{Introduction}

Professor John Haltiwanger is the recipient of the Global Award for Entrepreneurship Research 2020. He has made significant contributions to the field of entrepreneurship research, including data-driven research on industrial dynamics, entrepreneurship, and productivity. His work has broadened the policy debate on entrepreneurship and inspired professionals and academics alike all around the world.

One of Haltiwanger's contributions is to question the conventional wisdom of the job creation ability of small business. He provides evidence that large and mature firms account for most of the newly created manufacturing jobs and that these jobs are of higher quality than those in SMEs in that they are more likely to persist in subsequent years. A further major contribution refers to his work on the importance of firm age as opposed to size, showing that the job creation in small firms take place in the first few years of their existence, as captured in the "up-or-out" dynamics of young firms.

A second area of research pioneered by Haltiwanger is the decomposition of productivity growth into contributions from continuing, entering, and exiting firms. He shows that the largest component of growth can be attributed to continuing firms improving their productivity over time, for example, by gaining experience and learning about more efficient production techniques and profitable exploitation of existing market opportunities. The second largest component of productivity growth corresponds to net entry, i.e., the entry of firms with above-average productivity and the exit of firms with below-average productivity.

In recent years, Haltiwanger has also documented a decline in the rate of business startups and business dynamism, i.e., the pace of job creation and destruction, and flows of workers across firms. This trend could pose a serious problem for society to the extent that reallocation of workers towards higher productivity opportunities is important for productivity growth at the aggregate level.
Taken together, John Haltiwanger has made original and substantial contributions that advance our understanding of the role of small business and entrepreneurial firms in economic development. The value of his pioneering, meticulous, and facts-based work for the development of both entrepreneurship research and policymaking cannot be overstated.

This article provides a broad overview of Professor John Haltiwanger's contributions to entrepreneurship research.

\subsection{The Global Award for Entrepreneurship Research: brief background}

The Global Award for Entrepreneurship Research was initiated in 1996 and has since become the most prestigious prize in entrepreneurship research. It consists of 100,000 Euros and a statuette designed by the internationally renowned Swedish sculptor Carl Milles.

According to the original statutes, the award should be given to "a person who has produced scientific work of outstanding quality and importance, thereby giving a significant contribution to theorybuilding concerning entrepreneurship and small business development, the role and importance of new firm formation and the role of SMEs in economic development." The main aims of the award are (1) to highlight the importance of research produced in the areas of entrepreneurship and small business, (2) to further stimulate and promote research within these fields, and (3) to diffuse state-of-the-art research among scholars, practitioners, and people involved in small business development.

The domain of entrepreneurship research is broad (Carlsson et al., 2013), which means that entrepreneurship research that can be considered for the award is undertaken in several different disciplines, including economics, management, sociology, history, business administration, geography, and psychology. Any aspect of entrepreneurship research is eligible, including the environment and the organizations in which entrepreneurship is conducted, the character of the entrepreneur (personality, cognitive and affective aspects), or the role of the entrepreneur and/or the entrepreneurial function in a wider sense (at the level of the community, region, country, or industry).

One ambition of the Prize Committee is that the award-winning contributions, seen together over a 
longer time span, reflect the extraordinary breadth of entrepreneurship as a research field in the social sciences. The key criteria for prize-worthy contributions are originality and influence (Braunerhjelm \& Henrekson, 2009). It is recognized that contributions can be influential in many ways. A contribution can, for example, be influential because it has had a significant impact on subsequent scientific work, furthered entrepreneurship as a field (through creating important data bases or by starting influential journals, scientific communities, etc.), furthered entrepreneurship education and training at the academic level, and/or influenced policymaking and society more broadly.

When selecting prize-worthy contributions, the prize committee emphasizes the qualitative aspects of the contributions of candidates. Quantitative metrics, such as citation counts and impact factoradjusted publication volumes, do provide important information about candidates, but they will never replace qualitative judgment. This means that quantity will never substitute for quality, and it is even possible for a scholar to receive the award for a single landmark contribution.

\subsection{A short biography of the 2020 award winner: John Haltiwanger}

John Couch Haltiwanger was born on 12 December 1955, and is a citizen of the USA. He obtained a B.S. in Applied Mathematics and Economics from Brown University in 1977, and a Ph.D. in Economics from Johns Hopkins University in 1981. He then held academic positions on the faculty of University of California, Los Angeles (UCLA), and Johns Hopkins University, before joining the faculty at the University of Maryland in 1987, where he is currently the Dudley and Louisa Dillard Professor of Economics and Distinguished University Professor of Economics. Haltiwanger is a member of the Federal Economics Statistics Advisory Council, and is a research associate at both the Institute for the Study of Labor (IZA) and the National Bureau of Economic Research (NBER). Haltiwanger is also a Fellow of the Society of Labor Economics and the Econometric Society and has previously served on the Editorial Board of Small Business Economics.

John Haltiwanger's career is also marked by important contributions through public service.
In the late 1990s, Haltiwanger served as Chief Economist of the US Census Bureau. He currently continues his collaboration with the US Census Bureau through his role as Senior Research Fellow at its Center for Economic Studies. In addition, he has been a member of the Committee on National Statistics for the National Academy of Sciences, as well as a consultant for the Conference Board, and also a member of the Brookings Panel on Economic Activity.

Haltiwanger has received a number of honors and awards for his research. His 1996 book with Steven Davis and Scott Schuh on Job Creation and Destruction received widespread critical acclaim and also won the Choice Outstanding Academic Title in 1996. A subsequent book with Clair Brown and Julia Lane (Brown et al., 2006) won the same prize in 2007. He was also awarded the Julius Shiskin Memorial Award in 2013, and the 2014 Roger Herriot Award for Innovation in Federal Statistics (along with his co-authors John Abowd and Julia Lane), in recognition of his work with statistical agencies on the development of statistical and measurement methods to study firm dynamics.

John Haltiwanger has published over 100 academic articles in the world's most prestigious economics journals such as the American Economic Review, the Quarterly Journal of Economics, the Review of Economic Studies, the Review of Economics and Statistics, and the Journal of Economic Literature. In addition to these journal articles, he has published numerous book chapters and books. These publications have been highly influential in the areas of economics, management, and entrepreneurship.

\section{Overview of research}

Entrepreneurship means different things to different people. According to Wiklund et al. (2019, pp. 420-421), "entrepreneurship is a young discipline rooted in practice...there is no commonly accepted unifying definition of entrepreneurship." Some scholars define "entrepreneurship" as referring to innovation (Dennis, 2011) or to subjective growth ambitions (Henrekson, 2005; Reynolds et al., 2005) or to competition (Dennis, 2011). Another standard definition of entrepreneurship is that it refers to small firms 
below a certain size threshold (Van Praag \& Versloot, 2007). In Haltiwanger's view, entrepreneurship is the phenomenon of young firms. In one of his papers, he writes "we believe entrepreneurial activity is better represented by new businesses - that is, by age rather than size" (Decker et al., 2014, p. 4). More specifically, he considers that young firms are those with an age less than around 5 years (Decker et al., 2016b).

Haltiwanger has made a number of important contributions to scholarly understanding of entrepreneurship and the contribution of new and small business to the economy and to society. These contributions have taken the form of publications in books and in the world's leading economics journals, in the painstaking development of comprehensive new datasets, and through his contributions to policy and economic statistics through his role as Chief Economist at the US Census Bureau.

Haltiwanger's research has provided the foundations for modern understanding of job creation and destruction. His prize-winning 1996 book rigorously presented a catalogue of stylized facts about employment dynamics in small and large firms that has enabled a new generation of theorizing and scholarly understanding. More recently, his work on post-entry performance constitutes a landmark contribution in debates about the contribution of small firms vs young firms. Furthermore, his research into the secular changes in economic dynamism in the USA, as evidenced by declining rates of high-growth firms and startup job creation, has aroused interest and concern.

Haltiwanger's research has made significant contributions on an impressive range of themes. Anyone seeking to publish their research into job creation and destruction, productivity growth, life cycle dynamics, high-growth firms, and the contribution of entrepreneurship to the economy will find themselves drawing on previous work by Haltiwanger.

\subsection{Job creation and destruction}

Haltiwanger's contributions to our knowledge of job creation and destruction are primarily found in his prize-winning book (Davis et al., 1996a), which summarizes and extends the authors' previous research on the topic (such as Davis \& Haltiwanger, 1992).

Despite the importance of the topic of job creation, and ubiquitous concerns whether the turbulent economy would be capable of creating sufficient jobs, there was little existing evidence on the scale of job creation and destruction. The book, which is empirical in nature, therefore made an important contribution to the gap in the literature. This valuable evidence was obtained thanks to the painstaking efforts of Haltiwanger and colleagues to assemble the necessary database. Collaborating with staff at the Center for Economic Studies, US Bureau of the Census, Haltiwanger and colleagues further developed the Census of Manufactures and the Annual Survey of Manufactures into the Longitudinal Research Database (LRD). This resulted in a database of over 160,000 manufacturing plants and their parent firms. This in itself was a notable achievement: "the assembling of such a database is clearly an immense effort for which the authors and their co-workers deserve unqualified praise" (Haskel, 1998, p. 155). As entrepreneurship research has shifted emphasis from the analysis of cross-sectional data towards longitudinal data (Davidsson \& Wiklund, 2000), these data collection efforts are commendable.

The book includes several facts and results on job creation, job destruction, and job reallocation. Main results in the book include:

1) Rates of gross job creation and destruction are surprisingly large and persistent. In any 12-month period, around 1 in 10 manufacturing jobs were destroyed in one location and created in another. This challenged the view of firms as having a stable number of positions, and instead highlighted that firms are in a constant state of flux, with job creation and job destruction occurring simultaneously even within narrowly defined industries.

2) Most jobs that vanish over a period of 12 months fail to reappear in the following 2 years.

3) Job destruction rates vary more over the business cycle than job creation rates.

4) Gross job flow rates are lower at high-wage plants than those at low-wage plants.

5) Gross job flow rates are surprisingly unrelated to indicators of exposure to international trade. This helps to dispel the myth that trade is undermining job security by destroying large numbers of jobs.

6) The job-creating prowess of small businesses is less than previously thought and has been exaggerated in the literature because of statistical fallacies and misleading interpretations of the 
data. Correcting for these statistical fallacies, it appears that large, mature plants and firms account for most of the newly created (and newly destroyed) manufacturing jobs. Furthermore, jobs in SMEs are of a lower quality - newly created jobs in small plants are less likely to persist in subsequent years than newly created jobs at large employers. The "myth" of job creation by small business has led, according to the authors, to a disproportionately preferential policy treatment for small business that should be adjusted downwards.

7) Job creation and destruction rates are difficult to predict, using a list of variables such as industry, employer size, region, wages, and foreign competition. Instead, job creation seems driven by idiosyncratic factors. This has implications for policy: it is now more difficult to justify targeted industrial and commercial policies.

The book received widespread critical acclaim, heralded by many as a seminal contribution. The book review by Blanchflower (1997, p. 1400) writes that: "This is an important piece of work. Not many books start literatures. This one is likely to. Buy it." Haskel (1998, p. 156) considers that it is "a book which is a definitive documentation of job creation and destruction in the United States and has already proved to be the starting point for a rich body of work. How many other books can claim to be so influential in their field?" Burgess (1997, p. 1567) writes: "This is a seminal book, one which will make (indeed has already made) a significant change to the way in which macroeconomics and labor economics are thought about. It is a book that any economist would be pleased to have written: scholarly yet not turgid, new and controversial yet measured and reasonable, profound yet accessible."

\subsection{Small vs large vs young}

One of the prominent findings from the 1996 book was to dispel the myth of the job-creating prowess of small business (see in particular Davis et al., 1996a, Chapter 4). Haltiwanger and colleagues show that the conventional wisdom about the job-creating prowess of small business comes from statistical fallacies and misleading interpretations of the data. This issue was addressed head-on in Davis et al. (1996b). In this article, the authors show that the conventional wisdom of the job-creating prowess of small business is driven by statistical fallacies, analysis of flawed data, confusion between gross and net job creation rates, and misleading interpretations of the data. Instead, they argue that it is large plants and firms that contribute most of the newly created manufacturing jobs.

This in itself spawned a subsequent re-evaluation in the literature into the relative contribution of small and large employers (Davidsson et al., 1998; Neumark et al., 2011).

More recently, the debate has moved on from comparing the job creation of small vs large employers to the job-creating prowess of small firms vs young firms, thanks to the new impetus provided by a relatively recent article (Haltiwanger et al., 2013). Indeed, most small firms are young firms, but a rigorous statistical analysis can disentangle the two variables. The novelty in Haltiwanger et al. (2013) was not to suggest that firm growth rates may depend on age, because this had already been suggested by others, such as Fizaine (1968). Instead, the novelty was to provide high-quality large-sample evidence, involving data rich enough to zoom in on developments taking place in the first few years of a firm's existence. This contribution was made at a time when large-sample databases with information on firm age were rare (Decker et al., 2014).

Haltiwanger et al. (2013) turned the conventional view on its head, by showing that it is young firms, rather than small firms, that create the disproportionately large number of jobs. Controlling for age, they find that there is no longer any relationship between size and job creation. This has major implications for policy: job creation should be supported by targeting young firms rather than small firms. Small firms that are old should not be expected to create many jobs.

Haltiwanger et al. (2013) therefore initiated a debate on the relative contribution to job creation by small firms vs young firms. There have been many follow-up papers, including by entrepreneurship scholars, as researchers try to replicate, confirm, and extend his analysis. For example, focusing only on papers published in Small Business Economics that replicate and extend Haltiwanger et al. (2013), we can mention the multi-country studies by Ayyagari et al. (2014), Navaretti et al. (2014), Anyadike-Danes et al. (2015), and Criscuolo et al. (2017), as well as 
Lawless (2014) on Irish firms and Coad et al. (2018) on Swedish firms.

Another major contribution of Haltiwanger et al. (2013) is that most of the age-related effects of job creation seem to disappear after about 5 years. This interesting finding has raised the bar for empirical investigations into firm age and performance. Previously, entrepreneurship research had considered that firms with an average age of 12,16 , or 18 years were suitable samples for the analysis of the initial conditions of entrepreneurial firms (see the empirical literature that is surveyed in Bamford et al., 2004, Table 1). After Haltiwanger et al. (2013), researchers interested in age-related effects must have representative data on firms observed from their very first years.

\subsection{Decomposing productivity growth}

Another area of research pioneered by Haltiwanger and colleagues regards the relative performance of entrepreneurial firms in terms of their contribution to productivity growth. More specifically, Haltiwanger and colleagues decompose productivity growth in order to distinguish between the contributions from continuing, entering, and exiting plants or firms. This decomposition technique sheds light on the relative importance of underlying processes of learning, selection, reallocation, and creative destruction.

Foster et al. (1998) put forward the following decomposition of productivity growth:

$$
\begin{aligned}
\Delta \text { PROD }_{t}= & \sum_{i \in C} \theta_{i, t-1} \Delta \text { PROD }_{i t} \\
& +\sum_{i \in C}\left(\operatorname{PROD}_{i, t-1}-\overline{P R O D}_{t-1}\right) \Delta \theta_{i, t-1} \\
& +\sum_{i \in C} \Delta P R O D_{i t} \Delta \theta_{i t} \\
& +\sum_{i \in N} \theta_{i t}\left(\operatorname{PROD}_{i t}-\overline{P R O D}_{t-1}\right) \\
& -\sum_{i \in X} \theta_{i, t-1}\left(\operatorname{PROD}_{i, t-1}-\overline{P R O D}_{t-1}\right)
\end{aligned}
$$

where $\triangle P R O D_{t}$ corresponds to the share-weighted growth of productivity, for the period ending at time $t$. Plants or firms are indexed by $i$ and may be classified as either continuing $(\mathrm{C})$, entering $(\mathrm{N})$, or exiting (X). $\theta$ denotes the activity shares attributed to plant or firm $i$. Bars over variables indicate that the average has been taken over all the plants or firms.
Productivity can be measured either in terms of labor productivity (LP) or total factor productivity (TFP). ${ }^{1}$

The right-hand side of the equation decomposes productivity growth $\left(\triangle P R O D_{t}\right)$ into 5 terms, which (respectively) correspond to the within-effect, the between-effect, the covariance term, the contribution of entry, and the contribution of exit.

The contribution of continuing firms can be broken down into within effects, between effects, and a covariance term. Within effects correspond to changes in productivity within a firm, holding constant its market share. Within effects therefore correspond to the productivity growth that occurs within an individual firm, due to learning over time. Between effects correspond to the reallocation that occurs due to changes in the shares of plants. If the between effect is positive, this means that productive capacity is being reallocated from the least efficient towards the more efficient firms, in line with evolutionary theory (e.g., Nelson \& Winter, 1982). In contrast, if the between effect is negative, then the least productive firms are growing faster than the more productive firms. The covariance term, or cross term, will be positive if growing firms experience productivity growth as a consequence of their growth (e.g., if growth leads to economies of scale), and negative if firms with productivity increases have decreasing employment shares (e.g., if productivity growth occurs via downsizing).

Of particular interest to entrepreneurship scholars is the contribution to productivity growth due to net entry, which corresponds to the sum of the contribution to productivity of entry and exit. The effect of entry is positive if an entrant's productivity exceeds that of an average firm in the productivity distribution. The effect of exit is positive if exiting firms are less productive than the average firm - because in this case, the exit of underperforming firms allows resources to be reallocated to more productive uses.

Foster et al.'s (1998) methodology is considered to be the most common methodology for the decomposition of productivity growth (Holm, 2014). Overall, results of this type of analysis

\footnotetext{
${ }^{1}$ Labor productivity is an indicator of output per worker and therefore does not take into account the possibility that firms may have different capital intensities. TFP is an alternative indicator of productivity that calculates the efficiency of producing an amount of output using labor as well as capital inputs.
} 
suggest that the largest component of productivity growth is within-plant or within-firm learning. About one-third to one-half of the total productivity growth comes from the within component - according to which continuing plants or firms improve their productivity over time (holding size constant). Hence, an important mechanism for productivity growth is experience and learning about more efficient production techniques and more profitable exploitation of existing market opportunities. The second largest component of productivity growth seems to be the contribution due to net entry, which is due to entrants with above-average productivity, or the exit of firms with below-average productivity.

It is also worth mentioning a few publications by Haltiwanger that focus specifically on estimating the productivity of small firms. Baily et al. (1996) investigate the relationship between downsizing and productivity growth and find that continuing plants that have productivity growth do on average have decreases in employment. Haltiwanger et al. (1999) investigate how productivity relates to firm size and firm age.

\subsection{Declining business dynamism}

Some of Haltiwanger's more current research documents the decline in the pace of creative destruction and business dynamism in recent decades. This research provides a useful backdrop for contextualizing the trends and developments in contemporary entrepreneurship research and is of clear interest to policymakers. While Haltiwanger and colleagues focused on the USA, other scholars have confirmed these findings for other countries such as Belgium (Bijnens \& Konings, 2018).

In Decker et al. (2014), the authors observe that "the share of US employment accounted for by young firms has declined by almost 30 percent over the last 30 years" (Decker et al., 2014, p. 4). This has occurred alongside a decrease in the rate of business startups and a decline in the pace of "business dynamism" - measured as the pace of job creation and job destruction and flows of workers across firms (Decker et al., 2014). Furthermore, there has been deceleration in the activity of high-growth young firms since 2000 (Decker et al., 2016b).

Declining business dynamism is a serious problem because a dynamic economy requires the continuous reallocation of the factors of production towards the more efficient firms. If there is a decline in the rate of reallocation of workers towards higher-productivity opportunities, this will slow down productivity growth at the aggregate level (Decker et al., 2016a). Furthermore, if young firms with growth opportunities are finding it harder to grow fast after entry, this could be an obstacle to innovation and transformative entrepreneurship.

\section{Contributions to methodology}

In addition to the outstanding contributions mentioned in the previous section, this section presents some further research contributions in the form of methodological approaches and concepts developed by Haltiwanger. We start with Davis', Haltiwanger's, and Schuh's (DHS) growth rate indicator before discussing the concept of "up-or-out" dynamics.

\subsection{Measuring growth}

One of the problems facing research into firm growth is the non-trivial decision of how to measure growth. A common approach (e.g., Friedman, 1992) is to measure growth in terms of the change in an indicator of size (such as total sales or number of employees) denoted here as $X$, from time $t$ to time $t+1$, scaled down by initial size, i.e.:

Growth rate $=\frac{X_{t+1}-X_{t}}{X_{t}}$

However, a problem with this growth indicator is that it is not symmetric (Tornqvist et al., 1985): a firm growing from 10 employees in $t$, to 20 employees in $t+1$, and then back to 10 employees in $t+2$ to end up at its initial size, would be attributed a growth rate of $100 \%$ in $t+1$ but a growth rate of $-50 \%$ in the next period. This growth indicator could therefore exaggerate the growth rates of growing small firms. The problem arises because growth rates are calculated based on initial size $X_{t}$.

Figure 1 illustrates how the regression fallacy can exaggerate the job creation prowess of small firms. In the case of growth from time $t$ to time $t+1$, the 
Fig. 1 Illustration of how the regression fallacy exaggerates the job creation of SMEs. Notes: based on the numerical example in Davis et al. (1996a, p. 67)

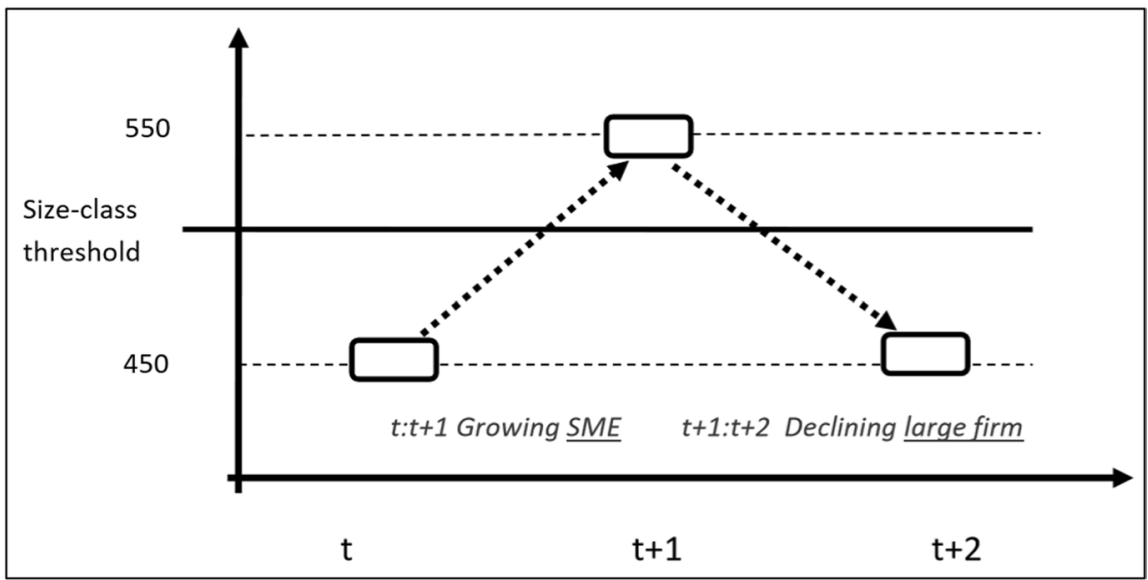

initial size is 450 employees, and the final size is 550 . The growth rate would usually be calculated as $(550-450) / 450=0.22$. Furthermore, given that initial size was below the size class threshold, this would be classified as a growing SME. In the case of growth over the period $(t+1: t+2)$, initial size is 550 and final size is 450 . The growth rate would be -0.18 , and this firm would be classified as declining large firm, because its initial size (at $t+1)$ was above the size threshold of 500. In this example, growth is mistakenly attributed to SMEs, and decline is mistakenly attributed to large firms. The problem therefore arises when continuing firms are assigned to a size category according to base year employment. Furthermore, the growth rate of the "SME" $(0.22)$ is larger in magnitude than the growth rate of the "large" firm $(-0.18)$, even though the firm is the same size in years $t$ and $t+2$.

Haltiwanger and colleagues also explain how other statistical fallacies can be misinterpreted as evidence of the job creation prowess of small business (Davis et al., 1996a, chapter 4). One such example would be the size distribution fallacy, which results from confusion about how to classify the share of employment of firms that migrate across size class boundaries. Another fallacy is the confusion between net job creation and gross job creation: small firms may make a large contribution to net job creation but a small contribution to gross job creation. Nightingale and Coad (2014) contains a further discussion of how other statistical fallacies all err on the side of exaggerating the job creation prowess of small business.
Haltiwanger and colleagues therefore put forward a new growth indicator (e.g., Davis \& Haltiwanger, 1992, p. 825):

$D H S=\frac{X_{t+1}-X_{t}}{\frac{1}{2}\left(X_{t}+X_{t+1}\right)}$

This growth indicator scales down the growth amount $X_{t+1}-X_{t}$ by the average size $\frac{1}{2}\left(X_{t}+X_{t+1}\right)$. It ranges from a theoretical minimum of -2 to a maximum of +2 . One statistical feature of this growth rate indicator is that it can take into account entry and exit events. When a firm exits, its final size $X_{t+1}$ is equal to zero; therefore, its growth rate is calculated as -2 . Similarly, when a firm enters, its initial size $X_{t}$ is equal to zero; therefore, its growth rate is calculated as $+2 .^{2}$

Applying the DHS growth indicator to the example in Fig. 1, the regression fallacy is avoided, because the growth rates for the periods $(t: t+1)$ and $(t+1: t+2)$ are the same in magnitude, and there is no problem of attributing growth to smaller firms and decline to larger firms. ${ }^{3}$

\footnotetext{
$\overline{2}$ See also Huber et al. (2017) for a critical discussion of the DHS growth indicator.

3 The growth rate for $t: t+1$ would be $(550-450) /(0.5 x$ $(450+550))$, which is equal in magnitude to the growth rate for $t+1: t+2$, which would be $(450-550) /(0.5 x(450+550))$. In both cases, the overall size of the firm would be considered to be the denominator of the growth rate indicator, i.e., $0.5 x$ $(450+550)$.
} 


\subsection{Up-or-out dynamics}

Haltiwanger's research has popularized the term "up-or-out" dynamics to refer to the post-entry struggles of new firms. "Up-or-out" dynamics here are interpreted as the dynamics of young firms who face uncertainty about their abilities (building on work by the 2019 prize winner of the Global Award for Entrepreneurship Research Boyan Jovanovic, Jovanovic, 1982) as well as a shifting business environment and dynamic forces of selection and learning effects. Young firms with superior capabilities and routines move "up" in terms of size and performance (e.g., productivity), while young firms that are revealed to have inferior capabilities are more likely to decline and exit from the market (Huber et al., 2017). Indeed, while the majority of new firms will exit in their first 5 years, the remaining survivors will show considerable average growth conditional on survival (Haltiwanger et al., 2013).

Foster et al. (2016) takes an alternative perspective to the post-entry performance of new establishments. Here, the authors put forward a dynamic model of post-entry growth that is driven by a demand accumulation process (e.g., building a customer base). This serves as a reminder to entrepreneurship scholars that the growth of new firms and new plants is not simply driven by setting up production capacity, but that it crucially depends on the steady accumulation of customers. The authors analyze a sample of US manufacturing plants in industries that are carefully selected because of the commodity-like nature of their products - e.g., ready-mixed concrete, cardboard boxes, and manufactured ice. Even in these sectors, new plants are smaller than established plants, and interestingly, these differences are not the result of supply-side cost differences. New plants are just as technically efficient as older plants, and may even be slightly more efficient, thereby having lower costs. However, young producers may appear to be less productive because they may charge lower prices at the start (Foster et al., 2006). The smaller size of new plants, despite them having a cost advantage, is explained by the slow process of accumulating a customer base (Foster et al., 2016). The results suggest that firms that price their outputs in order to influence future demand can benefit from stronger post-entry growth.

\section{Additional impact analysis}

Haltiwanger is widely regarded as an excellent academic, and has published in the most prestigious scientific journals, such as the American Economic Review and the Quarterly Journal of Economics. However, Haltiwanger's influence is not confined to academics.

Haltiwanger's writing style is relatively transparent and accessible to a non-technical audience. Haltiwanger has made efforts to investigate policy-relevant phenomena and also to communicate with policymakers. For example, his landmark 1996 book contains a chapter devoted to policy implications (see Davis et al., 1996a, Chapter 7). As a consequence, his research is appreciated by a wide audience that includes policymakers, statistical agency officers, and practitioners. The statistical and measurement methods that Haltiwanger helped to develop have been increasingly used by statistical agencies across the globe. Recognition for his work with statistical agencies is visible from him being awarded the Julius Shiskin Award for economic statistics in 2013, as well as the Roger Herriott Award for innovation in federal statistics in 2014.

Haltiwanger's research includes not only the rigorous statistical and econometric analysis of representative datasets, but he also took the relatively unusual steps towards an ambitious research program that required building and developing these datasets himself. ${ }^{4}$ While data collection and database construction may not be glamourous work, nevertheless, they are crucially important to improve our understanding of the phenomena of entrepreneurship and to provide the basis for subsequent theory-building. Haltiwanger's positions at the US Census Bureau, as Senior Research Fellow, and previously as Chief Economist, helped him to create the infrastructure and competences needed to make major breakthroughs in our understanding of job creation by entrepreneurial firms. Furthermore, Haltiwanger has taken commendable steps towards making his datasets available for replication and extension by other researchers. ${ }^{5}$

\footnotetext{
${ }^{4}$ For a recent example, see Decker et al. (2017), where the RE-LBD dataset combines industry and employment data from the Longitudinal Business Database of the US Census Bureau, with revenue data from tax records.

${ }^{5}$ See the links to data available on his website: http://econw eb.umd.edu/ haltiwan/.
} 
Haltiwanger's interest in the role of entrepreneurship in the wider societal context is also evidenced by a list that he has compiled of quotes made by US presidents in major addresses (such as the State of the Union addresses to Congress) regarding the job-creating prowess of small businesses. ${ }^{6}$ For example, every president since President Reagan has included statements such as that small businesses create at least two-thirds of net new jobs. This list that he has compiled, and shares with other researchers, has helped to highlight the political biases that may exaggerate the role of small business for the economy (Nightingale \& Coad, 2014).

\section{Conclusion}

John Haltiwanger's research is original and important and has been published in some of the world's most prestigious journals. He has had a significant impact on policymakers and national statistical offices around the world. Haltiwanger's tireless work collecting and analyzing representative datasets has provided a crucial "big picture" perspective on themes of job creation and destruction, post-entry growth, productivity dynamics, and the role of SMEs in economic development.

His 1996 book (Davis et al., 1996a) was a landmark contribution in terms of providing rich evidence on gross job flows and labor market dynamics. This book was immediately heralded as a seminal contribution. Among other things, the book re-evaluated the evidence regarding the job-creating prowess of SMEs. The book also introduced a novel methodology for measuring firm growth as a way of addressing some statistical biases. Subsequent research (Haltiwanger et al., 2013) was influential in redirecting the literature from focusing on job creation by SMEs to that of young firms. Haltiwanger and colleagues described an "up-or-out" dynamic whereby entering firms face high exit rates, but those that survive will experience rapid growth. Haltiwanger and colleagues have also evaluated the performance of SMEs by introducing a novel and influential methodology for decomposing productivity growth, and hence identifying the components of productivity growth coming from new entrants, exiting firms, and continuing firms. Furthermore, Haltiwanger has also received much attention from

\footnotetext{
${ }^{6}$ See Footnote 1 in Haltiwanger et al. (2013).
}

economists, entrepreneurship scholars, and policymakers recently for his findings about the secular decline of entrepreneurial dynamism in recent decades.

John Haltiwanger's contribution to entrepreneurship research is important, robust, relevant for policy, and highly influential. He is a worthy recipient of the Global Award for Entrepreneurship Research.

Open Access This article is licensed under a Creative Commons Attribution 4.0 International License, which permits use, sharing, adaptation, distribution and reproduction in any medium or format, as long as you give appropriate credit to the original author(s) and the source, provide a link to the Creative Commons licence, and indicate if changes were made. The images or other third party material in this article are included in the article's Creative Commons licence, unless indicated otherwise in a credit line to the material. If material is not included in the article's Creative Commons licence and your intended use is not permitted by statutory regulation or exceeds the permitted use, you will need to obtain permission directly from the copyright holder. To view a copy of this licence, visit http://creativecommons.org/licenses/by/4.0/.

\section{References}

Anyadike-Danes, M., Bjuggren, C. M., Gottschalk, S., Hölzl, W., Johansson, D., Maliranta, M., \& Myrann, A. (2015). An international cohort comparison of size effects on job growth. Small Business Economics, 44(4), 821-844.

Ayyagari, M., Demirguc-Kunt, A., \& Maksimovic, V. (2014). Who creates jobs in developing countries? Small Business Economics, 43(1), 75-99.

Baily, M. N., Bartelsman, E. J., \& Haltiwanger, J. (1996). Downsizing and productivity growth: Myth or reality? Small Business Economics, 8(4), 259-278.

Bamford, C. E., Dean, T. J., \& Douglas, T. J. (2004). The temporal nature of growth determinants in new bank foundings: Implications for new venture research design. Journal of Business Venturing, 19, 899-919.

Bijnens, G., \& Konings, J. (2018). Declining business dynamism in Belgium. Small Business Economics, 54(4), 1201-1239.

Blanchflower, D. (1997). Book review: Job creation and destruction. By Steven J. Davis, John C. Haltiwanger and Scott Schuh. Journal of Economic Literature, 35(3), 1398-1400.

Braunerhjelm, P., \& Henrekson, M. (2009). Awarding entrepreneurship research: A presentation of the Global Award. Entrepreneurship Theory and Practice, 33(3), 809-814.

Brown, C., Haltiwanger, J., \& Lane, J. (2006). Economic turbulence: Is a volatile economy good for America? University of Chicago Press.

Burgess, S. (1997). Book review: Job creation and destruction by Steven Davis, John Haltiwanger and Scott Schuh. Economic Journal, 107(444), 1567-1568.

Carlsson, B., Braunerhjelm, P., McKelvey, M., Olofsson, C., Persson, L., \& Ylinenpää, H. (2013). The evolving 
domain of entrepreneurship research. Small Business Economics, 41(4), 913-930.

Coad, A., Daunfeldt, S. O., \& Halvarsson, D. (2018). Bursting into life: Firm growth and growth persistence by age. Small Business Economics, 50(1), 55-75.

Criscuolo, C., Gal, P. N., \& Menon, C. (2017). Do micro startups fuel job creation? Cross-country evidence from the DynEmp Express database. Small Business Economics, 48(2), 393-412.

Davidsson, P., Lindmark, L., \& Olofsson, C. (1998). The extent of overestimation of small firm job creation - An empirical examination of the regression bias. Small Business Economics, 11(1), 87-100.

Davidsson, P., \& Wiklund, J. (2000). Conceptual and empirical challenges in the study of firm growth. In D. Sexton \& H. Landström (Eds.), The Blackwell Handbook of Entrepreneurship (reprinted 2006 in Entrepreneurship and the Growth of Firms, Elgar) (pp. 26-44). Blackwell Business.

Davis, S. J., \& Haltiwanger, J. (1992). Gross job creation, gross job destruction, and employment reallocation. Quarterly Journal of Economics, 107(3), 819-863.

Davis, S., Haltiwanger, J., \& Schuh, S. (1996a). Job creation and destruction. MIT Press.

Davis, S. J., Haltiwanger, J., \& Schuh, S. (1996b). Small business and job creation: Dissecting the myth and reassessing the facts. Small Business Economics, 8(4), 297-315.

Decker, R., Haltiwanger, J., Jarmin, R., \& Miranda, J. (2014). The role of entrepreneurship in US job creation and economic dynamism. Journal of Economic Perspectives, 28(3), 3-24.

Decker, R. A., Haltiwanger, J., Jarmin, R. S., \& Miranda, J. (2016a). Declining business dynamism: What we know and the way forward. American Economic Review Papers and Proceedings, 106(5), 203-207.

Decker, R. A., Haltiwanger, J., Jarmin, R. S., \& Miranda, J. (2016b). Where has all the skewness gone? The decline in high-growth (young) firms in the US. European Economic Review, 86, 4-23.

Decker, R. A., Haltiwanger, J., Jarmin, R. S., \& Miranda, J. (2017). Declining dynamism, allocative efficiency, and the productivity slowdown. American Economic Review Papers and Proceedings, 107(5), 322-326.

Dennis, W. J. (2011). Entrepreneurship, small business and public policy levers. Journal of Small Business Management, 49(1), 92-106.

Fizaine, F. (1968). Analyse statistique de la croissance des entreprises selon l'age et la taille. Revue D'économie Politique, 78(4), 606-620.

Foster, L., Haltiwanger, J., \& Krizan, C.J. (1998). Aggregate productivity growth: Lessons from microeconomic evidence. NBER working paper 6803.

Foster, L., Haltiwanger, J., \& Krizan, C. J. (2006). Market selection, reallocation, and restructuring in the US retail trade sector in the 1990s. Review of Economics and Statistics, 88(4), 748-758.

Foster, L., Haltiwanger, J., \& Syverson, C. (2016). The slow growth of new plants: Learning about demand? Economica, 83(329), 91-129.

Friedman, M. (1992). Do old fallacies ever die? Journal of Economic Literature, 30(4), 2129-2132.
Haltiwanger, J., Jarmin, R. S., \& Miranda, J. (2013). Who creates jobs? Small versus large versus young. Review of Economics and Statistics, 95(2), 347-361. https://doi.org/ 10.1162/REST_a_00288

Haltiwanger, J. C., Lane, J. I., \& Spletzer, J. (1999). Productivity differences across employers: The roles of employer size, age, and human capital. American Economic Review Papers and Proceedings, 89(2), 94-98.

Haskel, J. (1998). Book review: Job creation and destruction by Steven J. Davis, John C. Haltiwanger and Scott Schuh. Economica, 65(257), 154-156.

Henrekson, M. (2005). Entrepreneurship: A weak link in the welfare state? Industrial and Corporate Change, 14(3), 437-467.

Holm, J. R. (2014). The significance of structural transformation to productivity growth. Journal of Evolutionary Economics, 24(5), 1009-1036.

Huber, P., Oberhofer, H., \& Pfaffermayr, M. (2017). Who creates jobs? Econometric modeling and evidence for Austrian firm level data. European Economic Review, 91, 57-71.

Jovanovic, B. (1982). Selection and the evolution of industry. Econometrica, 50(3), 649-670.

Lawless, M. (2014). Age or size? Contributions to job creation. Small Business Economics, 42(4), 815-830.

Navaretti, G. B., Castellani, D., \& Pieri, F. (2014). Age and firm growth: Evidence from three European countries. Small Business Economics, 43(4), 823-837.

Nelson, R. R., \& Winter, S. G. (1982). An evolutionary theory of economic change. Belknap press of Harvard University Press.

Neumark, D., Wall, B., \& Zhang, J. (2011). Do small businesses create more jobs? New evidence for the United states from the National establishment time series. Review of Economics and Statistics, 93(1), 16-29.

Nightingale, P., \& Coad, A. (2014). Muppets and gazelles: Ideological and methodological biases in entrepreneurship research. Industrial and Corporate Change, 23(1), 113-143.

Reynolds, P., Bosma, N., Autio, E., Hunt, S., De Bono, N., Servais, I., Lopez-Garcia, P., \& Chin, N. (2005). Global entrepreneurship monitor: Data collection design and implementation 1998-2003. Small Business Economics, 24(3), 205-231.

Tornqvist, L., Vartia, P., \& Vartia, Y. O. (1985). How should relative changes be measured? American Statistician, 39(1), 43-46.

Van Praag, C. M., \& Versloot, P. H. (2007). What is the value of entrepreneurship? A review of recent research. Small Business Economics, 29(4), 351-382.

Wiklund, J., Wright, M., \& Zahra, S. A. (2019). Conquering relevance: Entrepreneurship research's grand challenge. Entrepreneurship Theory and Practice, 43(3), 419-436. https://doi.org/10.1177/1042258718807478

Publisher's note Springer Nature remains neutral with regard to jurisdictional claims in published maps and institutional affiliations. 